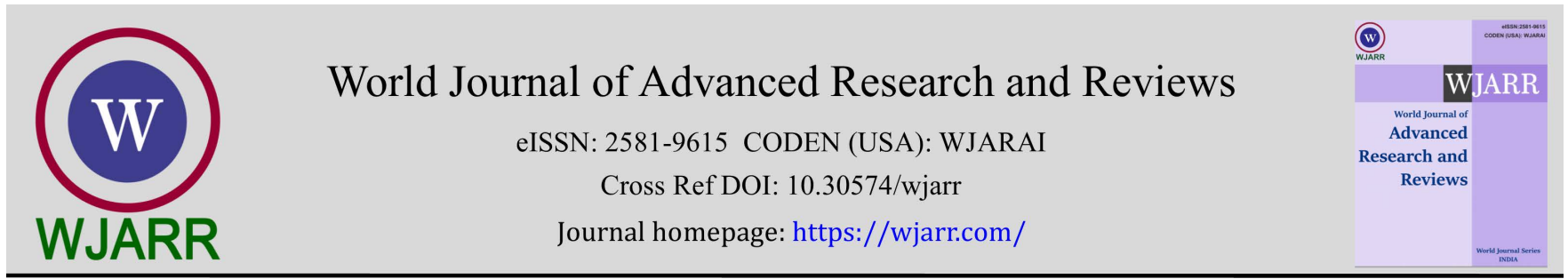

(RESEARCH ARTiCle)

\title{
Procurement sustainability in public institutions in Ghana - Case Study on selected second cycle institution in Bono and Bono East Region of Ghana
}

\author{
Graham Billa 1, Kelvin Gyamfi 2 and Moisob Adamu ${ }^{3 *}$ \\ ${ }^{1}$ C.K Tedam University of Technology \& Applied Sciences, Navrongo-Upper East. \\ 2 Local Government Service of Ghana, Box MB 396, Ministries-Accra. \\ ${ }^{3}$ Ahafo Ano South-West District Assembly, Box 9, Mankranso-Kumasi.
}

World Journal of Advanced Research and Reviews, 2021, 12(02), 492-499

Publication history: Received on 30 September 2021; revised on 07 November 2021; accepted on 09 November 2021

Article DOI: https://doi.org/10.30574/wjarr.2021.12.2.0562

\begin{abstract}
Environmental and social issues are increasingly being included in the strategy plans of public organizations. The people and variables that affect the pace with which sustainability measures are implemented are the subject of this article. The researchers looked at Selected Second Cycle Institutions in Bono East and Bono Regions of Ghana. The target group of this research were the Headmaster/Headmistress, Accountants and Procurement officers. A total of Forty-Eight 48 respondents answered the questionnaire posed to them by the researcher. Close-ended Questionnaires questionnaire was used in attaining views of respondents. Despite the fact that sustainability efforts were given, some of the institution stalled with fusing sustainability in the procurement cycle and lack of stakeholders' involvement. Procurement practitioners have little have relatively little impact on the sustainability implementation process.
\end{abstract}

Keywords: Procurement; Sustainability; Second Cycle Institution

\section{Background Information}

Organizations are increasingly recognizing the need to address the problem of sustainability in their operations. The Public Procurement Act 663 of 2003 as amended in Act 914 of 2016 has it in section (2) that, procurement is to be executed in environmentally and socially sustainable manner.

Chartered Institute of Procurement and Supply (6) defines In addition to conventional price and quality considerations, sustainable procurement entails integrating social, economic, and environmental issues into an organization's buying processes and procedures. This concept stems on meeting the immediate needs of end-users and not compromising with the future to environmental hazards. Due to the uncertainties and ambiguity of this concept, difficulties often emerge when trying to implement sustainability principles in reality since the future is taken into concentration as what is consume now. (17),came up with three dimensions that strengthens sustainability and they were environmental, social and economic consideration which when adhered to then metamorphosed into profitability, planet saving and environmental friendliness for all inhabitants.

The idea entails taking into account the economic, environmental, and social consequences of corporate operations at the same time (26). Procurement sustainability is not focusing on the public sector or the private sector alone. The adherence of the Public Procurement 663 of 2003 as amended in Act 914 of 2016 is not a law that governs the public sector but includes and bind the private sector. However, in the work of (29), Sustainability is a hot issue in the public sector these days. Given the scale and influence of the public sector in terms of its percentage share of a country's GDP, public procurement has the potential to contribute to long-term sustainability (24).

\footnotetext{
* Corresponding author: Moisob Adamu

Ahafo Ano South-West District Assembly, Box 9, Mankranso-Kumasi.

Copyright $(2021$ Author(s) retain the copyright of this article. This article is published under the terms of the Creative Commons Attribution Liscense 4.0.
} 
It's difficult to say whether the emphasis on private sector studies reflects a lack of public-sector sustainability efforts or if the public sector is just under-researched. The majority of research has focused on prominent public sector organizations and successful sustainability initiatives, limiting the generalizability of the results (13). Procedures, legal, and political restrictions confront managers in government entities. Furthermore, the effectiveness of sustainability efforts is influenced by a variety of internal and external stakeholders. These parties may have opposing objectives. This research looked at the industry players (drivers) and policy implementers in ensuring procurement sustainability is just not to be kept in the Public Procurement Act 663 of 2003 as amended in Act 914 of 2016 but ensuring that various stakeholders are involved in making it a reality.

\section{Statement of the Problem}

Public procurement is a tool of government policy in the development of a country. It also has a major impact on environmental problems as a consequence of excessive resource consumption from both construction and building operations, which pollutes the environment (8). Ghana is a developing country that spends a considerable amount of money on infrastructure development. In the year 2020 as at January, Government has spent 6.9 billion Ghana cedis on Goods and services which is huge capital investment on consumables. This, huge investment on goods and services calls for the government to be circumspect in adhering to Public Procurement Act 663 of 2003 and amended in Act 914 of 2015. However, procurement processes for these activities have considerable challenges since sanctions are not meted to non-compliance with procurement sustainability. Ghana uses 420 million Cedis (290 million dollar) each year to solve sanitation issue according to (16) the Act in terms of maintaining a sustainable environment. In terms of the environment, the Procurement Act, Act 663, which serves as a guide to the needs of the public procurement process, is silent on the subject of sustainability in public procurement activities. In Ghana, it has been shown that the procurement process ignores concerns about sustainability. The energy sector with respect to electricity was increased from 1,730 Megawatts (MW) in 2006 to 3,795 in 2016 (20). (20) reports that, 21.7\% gross of electricity was generated over the last decade, has been lost through transmission. Transmission loss account for an average of 3.9\% whilst $16.2 \%$ annually is loss is through commercial and households. These losses are attributed to obsolete materials used in the transmission processes, poor energy conservation practices by households and commercial organizations.

Procurement sustainability needs to be a cycle than being a spherical in procurement since environmental issues need special attention because they have a larger impact on procurement in developing nations than they do in developed ones. As a result, green procurement is essential for advancing the broader goal of sustainable procurement, which addresses environmental issues in labour procurement. As a consequence, this study looks at the environmental criteria that are used throughout the globe to ensure a sustainable environment via procurement, as well as the degree to Senior High Schools would follow what has been stipulated in the Public Procurement Act of Ghana.

\section{The research objective}

The objective of undertaking this research is to ascertain procurement sustainability in selected second cycle institutions in Bono East and Bono region of Ghana. The Specific objectives in this research are as follows;

- To ascertain the environmental consideration in sustainable procurement in selected second cycle institutions in Bono East and Bono Region of Ghana

- To identify the challenges that affect sustainable procurement in selected second cycle institutions in the Bono East and Bono Region of Ghana.

- To establish the primary environmental concern in connection to their operations of selected Second Cycle institutions in Bono East and Bono Region of Ghana

\subsection{Research Questions}

- What is environmental consideration in sustainable procurement in selected second cycle institutions in Bono region of Ghana?

- What are the challenges that affect sustainable procurement in selected second cycle institutions in the Bono region of Ghana?

- What are the primary environmental concern in connection to their operations of selected Second Cycle institutions in Bono East and Bono Region of Ghana? 


\section{Review of the Literature}

The public sector's long-term viability (Sustainability in Procurement)

It is an effective and compelling idea for communicating what sustainability means to a company. Instead of many separate projects and programs that are managed independently of one another, sustainability efforts must be connected to organizational strategy. To become a member of an organization, sustainability must be developed across the company.

Transparency allows for active communication with internal and external stakeholders in order to improve procedures, guarantee cooperation, and promote a broader range of vendors to compete for government contracts. Most public organizations incorporate sustainability factors in their buying, according to (4), but many elements of sustainability are not well handled. (12) claims that sustainable buying reduces risk to the environment, human health, and conventional pricing, quality, and functionality concerns. This implies that sustainable procurement results in habitat preservation, reduced use of natural resources, reduced manufacturing energy usage, no hazardous chemicals, energy efficient operations, low pollution, and recyclable materials. Sustainable procurement, according to (23), may be utilized as a tool for attaining both economic and environmental objectives, as well as a lever for supporting green procurement policy and planning (21).

The availability and use of procurement manual in an organization help the organization to incorporate the sustainable issues such as economic, social and environmental in procurement decision making.

\subsection{Challenges in Procurement Sustainability}

Labelling organizations, technical specialists, ecological foundations, the government, the media, as well as standards and regulatory bodies have all been recognized as non-business players and variables that influence sustainability efforts and credibility in the area (7).

Rather than being handled separately, sustainability efforts and business strategy must be tightly integrated. Top management support is often a major driver for effective implementation of programs, and it is typically a significant driver for success (31). Regulatory compliance, competitive advantage, stakeholder demands, ethical concern, and top management efforts have all been identified as specific motivations (2), this also affirmed in the Public Procurement Act 663 of 2003 as amended in Act 914 of 2016 where a procuring entity needs to ensure that materials procured are environmentally friendly. Section 16(1)(2) of the Act stipulate the strength of the Head of Entity in procurement activity since the head of Entity is the spending officer, should ensure full compliance of the Act in reference to section(2) of the Procurement Act. This indicates that the should be willingness of top management in respect procurement sustainability and the absence of that top management involvement would be very difficult for an organisation and a nation at large to achieve that object in procurement sustainability. (14), affirmed that, lack of top management support has the tendency to crippling the smoothness of ensuring that procurement is carried out with the objective of achieving sustainability in procurement. Lack of top management support, the expense of sustainability, unsuitable norms and laws, and a lack of knowledge among company executives would lead an organisation veering off the compliance with the legal and regulatory standard of the country in procurement sustainability. External obstacles include legislation, inadequate supplier commitment, and industry-specific restrictions, while internal impediments include budget constraints and lack of legitimacy. External rather than internal factors seem to have a greater impact on businesses (30).

When weighing trade-offs between competing procurement objectives and policies, such as prices, quality, timeliness, risk, economic goals, social purposes, competition, environmental protection, and green procurement, policymakers confront tough choices (28). Given the complexity and diversity of public procurement, as well as numerous parties and competing objectives (27), obstacles are likely to arise.

\subsection{Stakeholders}

Stakeholder theory tries to answer a basic issue in a systematic way: which groups are significant for a matter and, as a result, need adequate management attention, and which are not (22). Managers must be aware of all stakeholders, not only those who are financially dependent on them (18).

The involvement of stakeholders and the integration of their different needs is a crucial issue in the discussion on sustainability. Stakeholder analysis may show which stakeholders have the capacity to influence the sustainability 
implementation and success. A single political player often represents the interests of a wide number of other, relatively weak, stakeholders in public sector organizations.

Stakeholder demands, as well as the associated reputational and legal concerns, are often cited as a major motivator for enacting standards and codes of behavior. Stakeholder management is essential for achieving long-term success (1). Few studies have specifically addressed stakeholder issues in the context of sustainable sourcing (11). Internal stakeholder pressure from middle management, in particular, may be a powerful driver behind sustainability efforts (10). Buyers, suppliers, contractors, the community, and internal workers in most other functional divisions of the business engage with purchasing departments in a unique way (5). Stakeholder management is critical for environmental and social sustainability (9).

\section{Methodology}

Multi-stage and Purposive sampling technique was used in the conduct of this research. Multi-stage sampling technique was used in the conduct of this research. Two regions out of sixteen (16) regions were selected through cluster sampling technique and they were Bono East and Bono Region. Bono East has 28 senior High schools whilst, Bono Region has 35 Senior High Schools. In total, Sixty-Three (63) Senior High Schools were earmarked for this work. Simple random sampling technique was used in selecting the Senior High schools at each $9^{\text {th }}$ Term. Seven (7) Senior High Schools were then selected. These were made up of St. James Senior High School, S.D.A Senor High School, Sacred Heart Senior High School, Our Lady of Mount Carmel Girls Senior High, Atebubu Senior High, Amanten Senior High and Nkoranza Senior High Technical. The sample to be taken for study was put into three (3) strata. Purposive sampling Technique was adopted in attaining relevant information form key respondents who were put into strata because they were deemed fit to have the relevant information in the development of the research. These key personnel's were the principals (Headmaster/Headmistress), procurement Officers and Accountants. The staff strengths of the category of staff selected in the selected senior High Schools were fifty-five (55). The researcher used (19) to select a sample of 48 because the population for the study was fifty-five (55).

Table 1 The strata of Respondents

\begin{tabular}{|l|c|c|c|}
\hline Category of respondents & Study Population & Sample size & Percentage (\%) \\
\hline Procurement Officer/Stores & 20 & 17 & 35.4 \\
\hline Headmaster/headmistress & 7 & 7 & 14.6 \\
\hline Accountants & 28 & 24 & 50 \\
\hline Total & 55 & 48 & 100 \\
\hline
\end{tabular}

\section{Results and discussion}

The data obtained was analyzed using the Statistical Package for Social Sciences (SPSS). This statistical program produced quantitative data in the form of tables including numerical values and text (i.e Simple frequencies). Through the use of Excel, the Relative Importance Index (RII) was utilized to determine the acceptability level of several variables using a scale ranging from $1=$ strongly agree, 2 =agree, $3=$ neutral, $4=$ disagree, and $5=$ strongly disagree (Spreadsheet). Weights were produced using the RII using frequencies obtained using SPSS. The variables that were studied were also rated according to their RII scores. Mean scores, Standard Deviation (SD), RII, and Ranking make up the RII. The RII runs from $0-3.99$, which is considered unacceptable, to 4.0 and above, which is considered acceptable based on the mean response values.

From Table 2, respondents view was sought on issue that concerns the environment when procuring goods. The mean score for all the responses given, it was realised that, all the eight (8) factors had a mean score below 4.0 indicating that the institutions does not have process that is used in managing the environment when undertaking a procurement activity, they also exhibited that, there was no need to consider environmental quality when it comes to sustainable procurement decisions, there is no positive response that Public procurement decisions can contribute to the mitigation of extreme global climate change, there is little awareness on policy awareness binding them to include procur ement sustainability in their decision making. From the respondents, it can be deduced that there never believe that Sustainable procurement decisions can help prevent environmental quality deteriorations, Environmental sustainability is a priority has never been their priority, Tendering specifications has no such specification that includes 
environmental consideration and finally, never believe that Procurement activities influence environmental quality. Sustainability which is deeply entrenched in the public procurement Act is not being adhered to. Public Procurement Act 663 of 2003 as amended in Act 914 of 2016 where a procuring entity needs to ensure that materials procured are environmentally friendly. Section 16(1)(2) of the Act stipulate the strength of the Head of Entity in procurement activity since the head of Entity is the spending officer, should ensure full compliance of the Act in reference to section(2) of the Procurement Act. Head of Entity who to ensure full compliance of the Public Procurement Act have little interest with procurement sustainability. This was also affirmed by (15), that lack of top management support to sustainability of in procurement has the tendency of crippling the objectives of it.

Table 2 Environmental Considerations in Sustainable Procurement

\begin{tabular}{|c|c|c|c|c|c|}
\hline S/N & Factor & Mean Score & SD & RII & Rank \\
\hline 1 & $\begin{array}{l}\text { There are processes or systems implemented to manage your } \\
\text { environmental impact on projects }\end{array}$ & 3.10 & 5.13 & 62.08 & 1 \\
\hline 2 & $\begin{array}{l}\text { There is no need to consider environmental quality when it comes to } \\
\text { sustainable procurement decisions }\end{array}$ & 3.02 & 5.94 & 60.42 & 2 \\
\hline 3 & $\begin{array}{l}\text { Public procurement decisions can contribute to the mitigation of } \\
\text { extreme global climate change }\end{array}$ & 2.81 & 6.11 & 56.25 & 3 \\
\hline 4 & $\begin{array}{l}\text { There is a current statement or policy that commits you to } \\
\text { sustainability and/or reducing environmental impact during } \\
\text { procurement decision taking }\end{array}$ & 2.71 & 4.39 & 54.17 & 4 \\
\hline 5 & $\begin{array}{l}\text { Sustainable procurement decisions can help prevent environmental } \\
\text { quality deteriorations/degradation }\end{array}$ & 2.69 & 5.81 & 53.75 & 5 \\
\hline 6 & Environmental sustainability is a priority & 2.56 & 7.23 & 51.25 & 6 \\
\hline 7 & $\begin{array}{l}\text { Tendering specifications always include environmental } \\
\text { considerations }\end{array}$ & 2.54 & 6.58 & 50.83 & 7 \\
\hline 8 & Procurement activities influence environmental quality & 2.48 & 7.13 & 49.58 & 8 \\
\hline
\end{tabular}

Table 3 Challenges affect Sustainable Procurement in Ghana

\begin{tabular}{|l|l|c|l|c|c|}
\hline S/N & Factors & Mean Score & SD & RII & Rank \\
\hline 1 & Budget constrain & 3.35 & 6.02 & 67.08 & 1 \\
\hline 2 & Organizational attitude and incentives & 3.23 & 3.78 & 64.58 & 2 \\
\hline 3 & Availability of sustainable product and services & 2.90 & 7.80 & 57.92 & 3 \\
\hline 4 & Higher Initial costs of Green Products & 2.71 & 7.06 & 54.17 & 4 \\
\hline 5 & Insufficient Information about sustainable procurement & 2.69 & 7.44 & 53.75 & 5 \\
\hline
\end{tabular}

Five (5) factors were used as a means of attaining views from respondents as to the challenges they face in procurement sustainability in their various institutions. From the responses given, Budget constrain, organizational attitude and incentive, availability of sustainable product and services, higher initial cost of green product and insufficient information about sustainable procurement were weighed against a mean of acceptable of 4.0 whilst the mean of nonacceptable ranges from 0-3.99. it can be deduced that, the respondents view on the five factors were below 4.0, indicating that there was no challenges that curb their ability to abide by procurement sustainability. Labelling organizations, technical specialists, ecological foundations, the government, the media, as well as standards and regulatory bodies have all been recognized as non-business players and variables that influence sustainability efforts and credibility in the area (7). From the analysis it can be affirmed that, key officers who to ensure compliance of the procurement Act are not motivated and the media has been of little help in such fulfilment of sustainability. Top management support is often a major driver for effective implementation of programs, and it is typically a significant 
driver for success (31). Regulatory compliance, competitive advantage, stakeholder demands, ethical concern, and top management efforts have all been identified as specific motivations (3),

Table 4 Primary environmental concern in connection with its operations

\begin{tabular}{|l|l|c|c|c|c|}
\hline S/N & Factors & Mean Score & SD & RII & Rank \\
\hline 1 & Disposal of waste or by products & 3.44 & 4.72 & 68.75 & 1 \\
\hline 2 & There is procurement sustainability at each of procurement cycle & 3.21 & 5.55 & 64.17 & 2 \\
\hline 3 & How to save Power or electricity & 3.00 & 6.50 & 60.00 & 3 \\
\hline 4 & Procuring Recyclable Product & 2.85 & 5.13 & 57.08 & 4 \\
\hline 5 & Knowledge on Sustainable Procurement is widespread in Ghana & 2.81 & 3.51 & 56.25 & 5 \\
\hline
\end{tabular}

Respondents view was sought on five areas pertaining to the operation of these selected Senior High Schools in Ghana. The respondents view were that, Disposal of waste products, Procurement sustainability at each stage of procurement cycle, Energy saving through the use of electricity, Procuring of recyclable product and knowledge on procurement sustainability were all below the acceptable range of 4.0, indicating that, the respondents have taken little effort into consideration, the concerns of the environment when procurement is to be initiated and executed. This is in cognizance of where (20) asserts that, the energy sector with respect to electricity was increased from 1,730 Megawatts (MW) in 2006 to 3,795 in 2016 and despite the increment in MW there have been losses through the use of transmission, Usage (Commercial purposes and Households) when obsolete and poor energy conservative procedure are not being used which accounted for an average of $3.9 \%$ and $16.2 \%$ annually respectively.

\section{Conclusion}

From the findings, there are a number of factors that need to be looked at in order to ensure procurement sustainability is not only entrenched in law but in practice. Stakeholders (internal and external) should be concerned when issues of the environment are at stake and should take proactive positions to ensure that the Public Procurement Act is a tool to achieve that objective. End users of a product in these institutions under study are to ensure that they give specifications of products that are environmentally friendly and convenient to use, so that at each stage of the procurement cycle, such products will be budgeted from initiation to the execution stage.

\section{Compliance with ethical standards}

\section{Acknowledgments}

We like to show gratitude to the lecturers of Business School of Ghana Institute of Management and Public Administration (GIMPA) for their immense Support during the conduct of this study especially Professor Samuel Famiyeh (Senior Lecturer) and the various schools who were used for the study.

\section{Disclosure of conflict of interest}

All the authors declare that they have no conflict of interest to disclose.

\section{Statement of informed consent}

I have read, understood, and had the chance to ask questions about the information presented. I understand that my participation is completely optional, and that I am free to leave at any moment, for any reason, and without incurring any costs. I have received assurances that the information provided for this survey will be kept secure and anonymous. I'm aware that a copy of this permission form will be handed to me. 


\section{References}

[1] Asif, Muhammad, Searcy, Cory, Zutshi, Ambika, Fisscher, Olaf AM. An integrated management systems approach to corporate social responsibility. Journal of Cleaner Production. 56 October 2013; 7-17.

[2] Bansal P, Roth K. Why Companies Go Green: A Model of Ecological Responsiveness. The Academy of Management Journal. 2000; 43(4): 717-736.

[3] Bansal P, Roth K. Why companies go green: a model of ecological responsiveness. Academy of Management Jour nal. 2000; 43(4): 716-736.

[4] Brammer S, alker H. Sustainable procurement in the public sector: an international comparative study. International Journal of Operation \& Production Management. 2011; 31(4): 452-476.

[5] Carter, Craig \& Jennings, Marianne. The role of purchasing in corporate social responsibility: A structural equation analysis. Journal of Business Logistics. 2004; 25. 145 - 186.

[6] Chartered Institute of Purchasing and Supply. Ethical and Sustainable Procurement; Walk Free Foundation. 2011.

[7] Crespin Mazet F, Dontenwill E. Sustainable procurement: building legitimacy in the supply network. Journal of Purchasing \& Supply Management. 2012; 18(4): 207-217.

[8] Ding Grace KC. Sustainable Construction - the Role of Environmental Assessment Tools, Journal of Environmental Management. 2008; 86(3): 451-64.

[9] Ehrgott, M. Social and Environmental Sustainability in Supplier Management (European Management Publications). 2009.

[10] Ehrgott M, Reimann F, Kaufmann L, Carter CR. Social sustainability a selecting emerging economy suppliers. Journal of Business Ethics. 2011; 98(1): 99-119.

[11] Foerstl K, Reuter C,Hartmann E, Blome C. Managing supplier sustainability risks in a dynamically changing envi ronment - sustainable supplier management in the chemical industry. Journal of Purchasing \& Supply Managem ent. $2010 ; 16(2): 118-130$.

[12] Gary P. Sampson United Nations University Press, Tokyo, 2005, 315 pages. World Trade Review 2007; 6:149-51.

[13] Gelderman CJ, Semeijn J,Bouma F.Implementing sustainability in public procurement - the role of procurement managers, partypolitical executives and department heads. Journal of Public Procurement. 2015; 15(1): 66—92.

[14] Giunipero Hooker, Denslow, Giunipero Lc, Hooker Re, Denslow D. Purchasing And Supply Management Sustain ability: Drivers And Barriers. Journal of Purchasing \& Supply Management. 2012 18(4).

[15] Giunipero Larry, Ramirez Edward Swilley, Esther. The Antecedents and Consequences of E-Purchasing Tools Usage in Supply Management, Journal of Marketing Theory and Practice. 2012; 20(3): 279-292.

[16] Huang Y. Is Economic Volatility Detrimental to Global Sustainability?. The World Bank Economic Review 2011;26:128-146.

[17] Isen M. Developing a sustainable procurement strategy for fashion buyers in the German retail sector. Hamburg: s.n. 2012.

[18] Kamann DJF. Organizational design in public Journal of Purchasing \& Supply Management. 2007; 13(2):127-136.

[19] Krejcie Robert V, Morgan Dryle W. Detrmining sample size for research Activities, EDUCATIONAL AND PSYCHOLOGICAL MEASUREMENT. 1970.

[20] Kumi, Nyarko E. The electricity Situation in Ghana: Challenges and Opportunities; CGD policy paper. Washington, DC: Centre for Global Development. 2017.

[21] Meehan Joanne, Bryde David J. Business Strategy and the Environment. 2011; 20(2): 94 - 106.

[22] Mitchell RK, Agle BR, Wood DJ. Toward a Theory of Stakeholder Identification and Salience: Defining the Principle of Who and What Really Counts. The Academy of Management Review. 1997; 22(4): 853-886.

[23] Nijaki, Worrel. "Procurement for Sustainable Local Economic Development." International Journal of Public Sector Management. 2012; 25 (2): 133-53. 
[24] Preuss L. Adressing sustainable development through public procurement: the case of local government. Supply Chain Management: An International Journal, 2009; 14(3): 213-223.

[25] Public Procurement Act 663 of 2003 and amended in Act 914 of 2016.

[26] Sikdar SK. Sustainable development and sustainability metrics AIChE Journal. 2003; 49(8): 1928-1932.

[27] Uyarra E, Flanagan K. Understanding the innovation impacts of public procurement. European Planning Studies. 2010 Jan;18(1):123-143. https://doi.org/10.1080/09654310903343567

[28] Thai KV. Public procurement re-examined. Journal of Public Procurement. 2001; 1(1): 9—50.

[29] Walker, Walker H. Public procurement research at IPSERA—aligning research and practice, and future trends. Public Money \& Management. 2015; 35(2): 141-144.

[30] Walker H, Di Sisto L,McBain D. Drivers and barriers to environmental supply chain management practices: lessons from the public and private sectors. Journal of Purchasing \& Supply Management. 2008; 14(1):69-85.

[31] Zhu Q, Sarkis J, Lai KH. Green supply chain management implications for 'closing the loop'. Transportation Rese arch Part E. 2008; 44(1): 1-18. 